\title{
Chicken feather waste degradation by Alternaria tenuissima and its application on plant growth
}

Mannu Kumari

Department of Microbiology, Dolphin PG College of Science and Agriculture, Chunni kalan Fatehgarh sahib-140307, (Punjab), India

Jitendra Kumar*

Department of Botany, Dolphin PG College of Science and Agriculture, Chunni kalan Fatehgarh sahib-140307, (Punjab), India

*Corresponding author. E. mail: jeetmicro@gmail.com

\section{How to Cite}

Kumari, M. and Kumar, J. (2020). Chicken feather waste degradation by Alternaria tenuissima and its application on plant growth. Journal of Applied and Natural Science, 12(3): 411 - 414.https://doi.org/10.31018/jans.v12i3.2345

\section{Article Info}

https://doi.org/10.31018/

jans.v12i3.2345

Received: August 5, 2020

Revised: September 1, 2020

Accepted: September 4, 2020

\begin{abstract}
The use of chicken as food is rising day today and as byproduct 8.5 billion tons, poultry feathers are produced worldwide, whereas India contributes about 350 million tons per annum. It is a waste product of poultry industries, are considered a potential high-quality protein supplement owing to their crude protein content of more than $85 \%$. In the present study Alternaria tenuissima a keratinophilic fungus was used for feather degradation in submerged state fermentation and soil. Total Protein releases were studied in submerged state fermentation by $A$. tenuissima are $122 \mu \mathrm{g} / \mathrm{ml}$ and $238 \mu \mathrm{g} / \mathrm{ml}$ in 15 and 25 days respectively. Lysine, Methionine, Cysteine and Valine were found $15.8,6.8,20.2,7.5 \mu \mathrm{g} / \mathrm{ml}$ in 25 days, respectively. Chicken feathers were mixed with soil and inoculated with spore suspension for degradation of complex keratin protein into simpler organic forms. $A$. tenuissima degraded feathers in soil and enhances nutritional value. Five-gram feathers in $250 \mathrm{~g}$ soil mixtures were found better growth enhancers and increased height. This work will reduce the solid waste generated in the form of feathers from the poultry industry, and convert it into a simpler organic form that can be used by plants.
\end{abstract}

Keyword: Biofertilizer, Feather compost, Keratinophilic fungi, Keratinase

\section{INTRODUCTION}

Feathers are biological waste produced in large volumes by the poultry processing industry, and their microbial degradation is for the generation of end products with benefits to the manufacturers in setting up ecological and economic strategies (Kim and Patterson 2000). Traditional approaches have restrictions for producing digestible feather meal force the use of microbial degradation of feather wastes as environmentally safe, low-cost methods (Gupta and Ramnani 2006). Keratin degradation is attracting biotechnological attention since it might provide a substitute way of waste management as well as the production of valuable products (Brandeli and Riffel 2006, Pasupuleti et al., 2010). Bacillus was used for their keratinases production, optimization and characterization (Sahoo et al., 2012, Dong et al., 2017, Arokiyaraj et al., 2019). Tiwary and Gupta (2012) used Bacillus licheniformis to study the conversion of the chicken feather into feather meal. Recycled keratin wastes and other organic wastes can be used as soil alterations and nourish- ments to provide organic matter for biologically vital and productive soils (Zheljazkov 2005). Soil samples treated with feather found variation in physiochemical composition to control (Ibrahim et al., 2014). The protein-rich concentrates feather meal formed for poultry feed can also use as a semi-slow release of nitrogen fertilizer (Kumar et al., 2017). Bacillus sp. was used to develop chicken feather compost from feathers waste and to promote plant growth activity (Nagarajan et al., 2017, Tamreihao et al., 2019). Keratinophilic fungi were isolated for their taxonomical aspect by several workers (Deshmukh and Verekar 2006, Deshmukh et al., 2010, Sharma 2016, Bairwa and Sharma 2020). However, few records are available in which fungi were used for the application of fertilizing potential of feather waste for enhancing plant growth as Chrysosporium tropicum and Malbranchea sp. (Kumar et al., 2017), Aphanoascus keratinophillus and C. tropicum (Bohacz et al., 2020). In the present study, A. tenuissi$m a$, a keratinolytic fungus was used to degrade feathers into submerged state fermentation and soil. The 
effect of feather waste supplemented soil was studied on the growth of Chickpea, Cicer arietinum.

\section{MATERIALS AND METHODS}

Microorganism: Alternaria tenuissima (NCBI accession no MN027926, named as $A$. tenuissima isolate A1) was used in the present study. Preserved fungi were subcultured on Potato dextrose Agar (Fig 1).

Degradation of feathers in submerged state fermentation: The media were prepared by the method of (Kumar and Kushwaha, 2014) containing sets of flasks that were marked as a Fungal control (FC), Keratin control (KC), and tests ( $\mathrm{T})$. The tests were inoculated with a disc of fungus Alternaria tenuissima. The flasks were incubated at $28^{\circ} \mathrm{C}$ for $5,10,15,20$, and 25 days in shaking conditions.

Estimation of protein and amino acids: Culture filtrate from each flask was centrifuged, and the supernatant was used for protein assay (Lowry et al., 1951) and amino acid (McGrath, 1972). The results of protein estimation are expressed as total protein i.e. the sum of the measured value of the test sample, fungus control, and keratin control.

Preparation of feather compost: Feather compost was developed by Sekar et al., (2015) as follows: The soil was collected from the agricultural field adjacent to Dolphin College Chunni kalan Punjab and chicken feathers were collected from poultry shops. Collected feathers were washed with detergent and tap water, air dried, and autoclaved. The control contained only soil, no feathers were added and marked as sample $A$, while samples $B, C, D$, and $E$ were mixed with $2,3,4$, and $5 \mathrm{~g}$ autoclaved feathers with soil respectively. All samples were inoculated with $20 \mathrm{ml}$ of aqueous spore suspension of $A$. tenuissima of 5 day old culture. Feather compost preparations were kept for degradation for 25 days. The box was covered regularly moistened

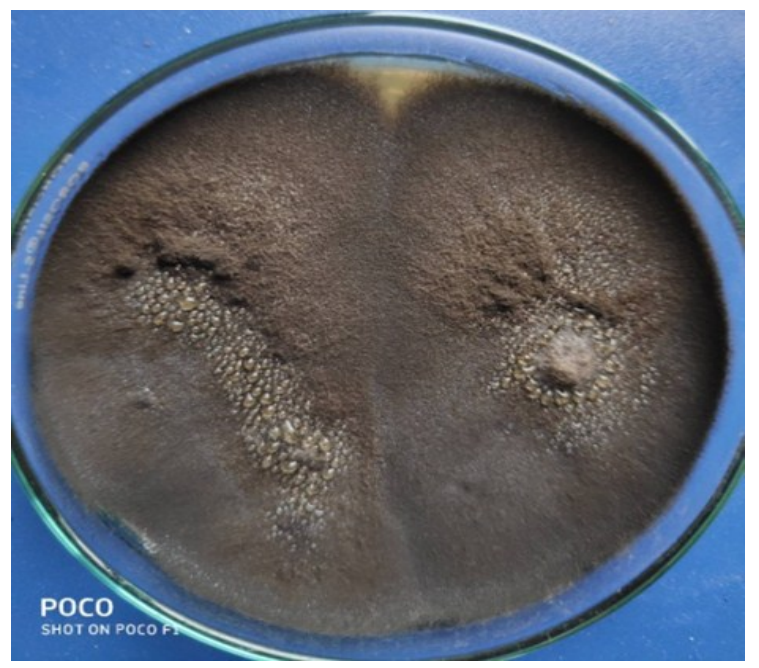

Fig. 1. Growth of Alternaria tenuissima on potato dextrose agar medium. with sterilized water and mixed. The morphological change was analyzed.

In vitro experiments on plants growth: Pod experiments were performed by the method of Nagarajan et al., (2017) with some modifications that were as follows: The seeds of Chickpeas were sowed to pods $A$, $B, C, D$, and $E$. The pods were grown in triplicate at temp $25-15^{\circ} \mathrm{C}$, relative humidity $65-70-\%$. The pods were watered every day to keep water holding capacity. The morphological analysis of the plant was done at intervals of the 5 day.

\section{RESULTS AND DISCUSSION}

Estimation of total protein release and amino acid: The $A$. tenuissima moderately degraded feathers. The protein content released into the supernatant due to the degradation of feathers is given in Table 1. Total protein release in submerged state fermentation was $122 \mu \mathrm{g} / \mathrm{ml}$ and $238 \mu \mathrm{g} / \mathrm{ml}$ in 15 and 25 days incubation respectively. Cysteine, Lysine, Methionine and Valine were released as 20.2, $15.8,6.8$ and $7.5 \mu \mathrm{g} / \mathrm{ml}$ in 25 days. The release of protein and amino acid in submerged state fermentation represented that degraded feather improved soil nutritional value by adding amino acids and oligopeptides. Parihar and Kushwaha, (2000) observed $107.66 \mu \mathrm{g} / \mathrm{ml}$ protein release by Chrysosporium indicum. Gousterova et al., (2005) studied examined fungi for the estimation of protein and amino acid in submerged state fermentation and found maximum by $C$. tropicum $432.66 \mu \mathrm{g} / \mathrm{ml}$. Bohacz et al., (2020) studied chicken feathers degradation by Aphanoascus keratinophilus and C. tropicum and recorded $400 \mu \mathrm{g}-1500 \mu \mathrm{g}$ in 6 weeks. Lysine and cysteine production by $C$. tropicum and Malbranchea sp. was 12.98 and $23.4 \mu \mathrm{g} / \mathrm{ml}$ in 20 days respectively (Kumar et al., 2017).

Preparation of soil feather compost: Feathers were found degraded in 25 days. Throughout the composting process, the keratinous material was observed for morphological changes that occurred due to the colonization of fungus. The processing of compost initially resulted in an increase in $\mathrm{pH}$ and fungi degraded the feathers in soils. Gousterova et al., (2005) used Thermoactinomycetes and used it in feather composting purposes and degraded feathers in submerged and exposed soil.

In vitro experiments on plants growth: The effect of feather compost on the growth of Chickpea seed was observed on control (without feather compost) and treated plants (containing feather compost) as shown in Fig. 2 \& 3. A regular rise in height was observed in feather compost potted plants except for pod B may be due to contest for nutrients between fungus and plant sample containing less amount of feathers. The pod length observed in Chickpea seeds was as follows E> 
Table 1. Total protein and amino acids release in submerged state fermentation.

\begin{tabular}{llllll}
\hline & \multicolumn{5}{c}{ Protein and amino acid release $\boldsymbol{\mu g} / \mathbf{m l}$ (Incubation period in days ) } \\
\cline { 2 - 6 } & $\mathbf{5}$ & $\mathbf{1 0}$ & $\mathbf{1 5}$ & $\mathbf{2 0}$ & $\mathbf{2 5}$ \\
\hline Total protein $^{* *}$ & 089.40 & 107.70 & 122.00 & 217.70 & 238.00 \\
Lysine $^{*}$ & 11.4 & 12.2 & 14.3 & 15.1 & 15.8 \\
Methionine $^{*}$ & 5.2 & 5.7 & 6.3 & 6.4 & 6.8 \\
Cystien $^{*}$ & 15.1 & 18.3 & 19.2 & 19.8 & 20.2 \\
Valine* $^{*}$ & 6.3 & 6.5 & 6.8 & 7.2 & 7.5 \\
\hline
\end{tabular}

Total protein (sum of keratin control + Test sample) ** readings mean of triplicate*

Table 2. Growth of Chickpea plants in feather supplemented soil.

\begin{tabular}{|c|c|c|c|c|c|}
\hline & \multicolumn{5}{|c|}{ Sample } \\
\hline & $\mathbf{A}$ & B & $\mathbf{C}$ & & $E$ \\
\hline Feather Condition & No feather & Colonization occurred & Moderate degradation & Degradation & Degradation \\
\hline Height (cm) & 10.2 & 9.1 & 11.5 & 15.3 & 16 \\
\hline Growth condition & Slow & Stunted & Normal & Good & Good \\
\hline Root development & Normal & Stunted & Moderate & Good & Maximum \\
\hline
\end{tabular}

D> C> A > B. Length of the shoot was 1.4 times increased in compassion to control (Table 2). Feather supplemented pot showed greener leaves and root length of the plant were increased. The number of leaves was $50 \%$ increased in feather supplemented soil. The effectiveness depends on the degradation capability of microorganisms. Adetunji et al., (2012) used organic fertilizers at a rate of $30 \%$ and found good growth and yield, and least susceptibility to diseases, as compared for control in the case of cowpea. Kumar et al., (2015) found better growth in pea plants supplemented with decomposed feathers. Feather compost controls plant growth after complete degradation although undegraded feather not supporting the plant growth. Degraded feather treated samples found enhanced root and shoot (Nagarajan et al., 2017). Oluwaseun et al., (2018) studied biodegradation of feather waste by keratinase enzyme and reported its positive effect on tomato plants. Feather protein degradation

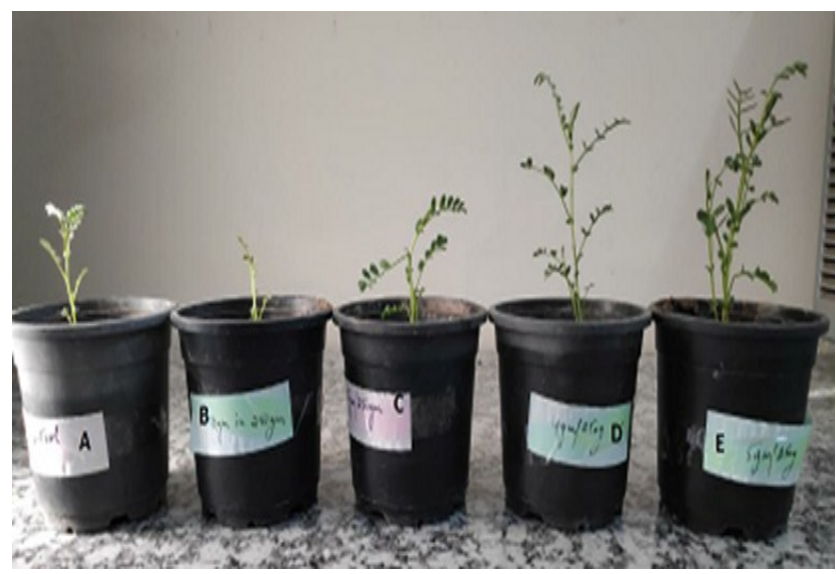

Fig. 2. Chick pea growth on feather compost. enhances the protein and amino acid contents which increases water retention capacity and moister content of the soil which is favourable for abundant growth. All workers supported that feather compost supplemented plant showed better growth.

\section{Conclusion}

The present study concluded that $A$. tenuissima was found efficient for feather degradation and increased the nourishing value of the soil by adding proteins $(238 \mu \mathrm{g} / \mathrm{ml})$ Cysteine $(20.2 \mu \mathrm{g} / \mathrm{ml})$, Lysine $(15.8 \mu \mathrm{g} /$ $\mathrm{ml})$, Methionine $(6.8 \mu \mathrm{g} / \mathrm{ml})$ and Valine $(7.5 \mu \mathrm{g} / \mathrm{ml})$ in 25 days. The quality of nutrients in the soil depended on the keratin degradation capability of keratin degrading fungi. An accurate amount of fungal inoculums and soil feathers mixture is still an issue. Work on these fungi could solve the environmental issue of poultry waste management and the production of lowcost fertilizers.

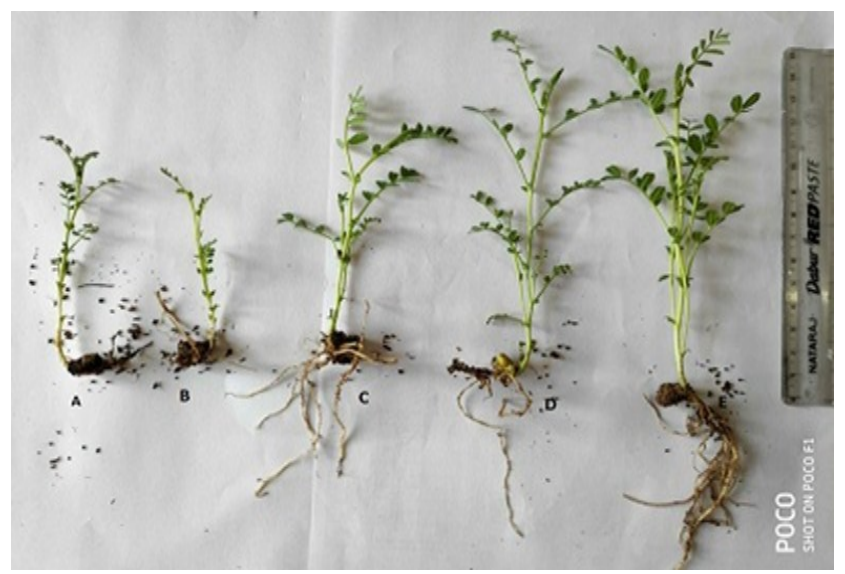

Fig. 3. Uprooted chick pea sample demonstrating shoot length. 


\section{REFERENCES}

1. Adetunji, C.O., Makanjuola, O.R., Arowora, K.A., Afolayan, S.S., Adetunji, J B. (2012). Production and application of keratin-based organic fertilizer from microbially hydrolyzed feathers to cowpea (Vigna unguiculata). International Journal of Scientific \& Engineering Research, 3 (12): 1-9.

2. Arokiyaraj, S., Vargese, R., Ahmad, B.A., Duraipandyan, V., Al- Dhabi, N.A. (2019). Optimizing the fermentation conditions and enhanced production of keratinase from Bacillus cereus isolated from halophilic environment. Saudi Journal of biological sciences, 26:378-381.

3. Bairwa, S., Sharma, M. (2020). Isolation and purification of keratinophilic fungi and dermatophytic fungi from some public places of Jaipur city India. International Journal of Pharma and Bioscience, doi 10.22376/ijpbs.2020.11.1.b6-10.

4. Bohacz, J., Kornillowicz-Kowalska, T., Kitowski, I., Ciesielska, A. (2020). Degradation of chicken feathers by Aphanoascus keratinophillus and Chyrsosporium tropicum strains from pellets of predatory birds and its practical aspect. International Biodeterioration \& Biodegradation, 151(2020): 104968.

5. Brandelli, A., Riffel, A. (2005). Production of an extracellular keratinase from Chryseobacterium $\mathrm{sp}$. growing on raw feathers. Elect J. Biotech, 8(1).

6. Deshmukh, S.K., Verekar, S.A. (2006). The occurrence of dermatophytes and other keratinophilic fungi from the soils of Himachal Pradesh (India). Czech Mycol, 58(1-2): 117-124.

7. Deshmukh, S.K., Verekar, S.A., Shrivastav, A. (2010). The occurrence of keratinophilic fungi in selected soils of Ladakh (India). Natural Science, 2(11): 1247-1252.

8. Dong, Y., Chang, W., Chen, P.T. (2017). Characterization and over expression of a novel keratinase from Bacillus polyfermenticus B4 in recombinant Bacillus subtillis. Bioresources and Bioprocessing, 4:47. doi 10.1186/s40643-017 -0177-1.

9. Gousterova, A., Braikova, D., Goshev, I., Christov, P., Tishinow, K. et al. (2005). Degradation of keratin and Collagen containing wasted by newly isolated thermoactinomycetes by alkaline hydrolysis. Lett. Appl. Microbiol, 40:335-340.

10.Gupta R, Ramnani P. (2006). Microbial keratinases and their prospective applications: an overview. Appl. Microbiol. Biotechnol, 70: 21-33.

11.Ibrahim, A.D., Rabah, A.B., Ibrahim, M.L., Magami, I.M., Isah, J.G. et al. (2014). Bacteriological and chemical properties of soil amended with fermented poultry bird feathers. Int. J Biol. Chem. Sci, 8(3): 1243-1248.

12.Kim, W.K., Patterson, P.H. (2000). Nutritional value of enzyme or sodium hydroxide- treated feathers from dead hens. Poult. Sci. 79:528-534.

13.Kumar, J., Kushwaha, R.K.S. (2014). Screening of fungi efficient in feather degradation and keratinase production.
Arch. Appl. Sci. Res, 6(1): 73-78.

14.Kumar, J., Kumar, P., Kushwaha, R.K.S. (2015). Feather waste degradation by keratinophilic fungi: An alternative source for protein and amino acid. Adv. Appl. Sci. Res, 6 (11): 160-164.

15.Kumar, J., Sharma, A., Kumar, P., Kushwaha, R.K.S. (2017). Enhancement of soil nutrition using fermented feather and their efficacy on seed germination. Int. $J$ of Pure and Appl. Biosci, 5(1): 92-98.

16.Lowry, O.H., Rosebrough, N.J., Farr, A.L., Ranjall, R.J. (1951). Protein measurement with Folin-phenol reagent. J. Biol. Chem, 193:265-275.

17.McGrath, R.,(1972). Protein measurement by ninhydrin determination of amino acids released by alkaline hydrolysis. Anal. Biochem, 49: 95-102.

18.Nagarajan, S., Eswaram, P., Masilamani, R.P., Natarajan, H. (2017).Chicken feather compost to promote the plant growth activity by using keratinolytic bacteria. Waste biomass valor, doi: 10.1007/s12649-017-0001-0.

19. Oluwaseun, A.C., Paomlpem, P., Sarin, N.B. (2018). Production of eco-friendly biofertilizers produced from crude and immobilized enzymes from Bacillus subtillis $\mathrm{CH} 008$ and their effect on the growth of Solanum lycopersicum. Plant Arch. 18(2):1455-1462.

20.Parihar, P., Kushwaha, R.K.S. (2000). Rapid degradation of human hair by Chrysosporium indicum isolated from soil of Thailand. Microbes: Agriculture, Industry and Environment, Bisen Singh Mahendra Pal Singh Dehradun India, 177-181.

21.Pasupuleti, V.K., Holmes, C., Demain, A.L. (2010). Applications of protein hydrolysates in biotechnology. Springer Netherlands, pp. 1-9.

22.Sekar, V., Kannam, M., Sivakumar, N., Dheeba, B., Raju, M. (2015). Efficacy of poultry feather decomposition by native isolates of bacillus $\mathrm{sp}$. and its impact on mineralization. Res. J. Pharma. Biolog and Chem. 6(1): 852-859.

23.Sharma R. (2016). Some keratinophilic fungi new to India. J. Mycopathol. Res, 54(1): 35-39

24.Sahoo, D.K., Thatoi, H., Mondal, K.C., Mohapatra, P.K.D. (2012). Keratinase production and biodegradation of whole chicken feather keratin by a newly isolated bacterium under submerged state fermentation. Appl. Biochem. Biotech, 167: 1040-1051.

25.Tamreihao, K., Mukherjee, S., Khunjamayum, R., Jayadevi, L., Asem, R.S. et al. (2019). Feather degradation by keratinolytic bacteria and biofertilizing potential for sustainable agriculture production. J. of Basic Microbiol, 59: 4-13. Doi:10.1002/jobm201800434

26. Tiwary E, Gupta R. (2012). Rapid conversion of chicken feather to feather meal using dimeric keratinase from $\mathrm{Ba}$ cillus licheniformis ER-15. Bioprocessing and Biotechniques, 2:4. doi.org/10.4172/2155-9821.1000123

27.Zheljazkov, V.D. (2005). Assessment of wool waste and hair waste as soil amendment and nutrient source. J. Environ. Qual, 34: 2310-2317. 